\title{
СИТУАЦИЯ ЭКЗИСТЕНЦИАЛЬНОЙ ТРЕВОГИ И ПОИСК ТРАНСЦЕНДЕНТНОГО СМЫСЛА СУЩЕСТВОВАНИЯ
}

\section{THE SITUATION OF EXISTENTIAL ANXIETY AND THE SEARCH FOR A TRANSCENDENTAL MEANING OF EXISTENCE}

V. Savrey

Summary: The alarm of the global threat that struck the world in the spring of 2020 made humanity shudder, wake up from being immersed in everyday idleness and vanity, and think deeply about the high and innermost human destiny, in which the predecessors of modern generations have faithfully believed throughout historical epochs. It is time to reassess the cultural paradigm of the new time, with its state of intoxicating euphoria caused by the achievements of scientific and technological progress, comfortable conditions of material existence, the loss of a responsible attitude to the meaning of human existence. The article reflects a range of philosophical, religious-ethical and existential problems.

Keywords: God, immortality, eternity, peace, responsibility, path, religion, freedom, transcendence, anxiety, philosophy, Christianity, existence, epoch, man.

\author{
Саврей Валерий Яковлевич \\ Д.ф.н., профессор, МГУ им. М.В. Ломоносова \\ vsvry@icloud.com
}

Аннотация: Тревога глобальной угрозы, обрушившаяся на мир весной 2020 года, заставило человечество вздрогнуть, очнуться от погружённости в повседневную праздность и суету, глубоко задуматься о высоком и сокровенном человеческом предназначении, в которое свято верили предшественники современных поколений на протяжении исторических эпох. Наступила пора переоценки культурной парадигмы нового времени, с её состоянием упоительной эйфории, вызванной достижениями научно-технического прогресса, комфортными условиями материального существования, потерей ответственного отношения к смыслу человеческого существования. В статье нашёл отражение спектр философских, религиозно-этических и экзистенциальных проблем.

Ключевые слова: Бог, бессмертие, вечность, мир, ответственность, путь, религия, свобода, трансцендентность, тревога, философия, христианство, экзистенция, эпоха, человек.
$\mathrm{B}$ своей «Системе трансцендентального идеализма», написанной в марте 1800 года, Ф.В.И. Шеллинг утверждал, что «ни одно государственное устройство в отдельности, будь оно самым совершенным по идее своей, не может рассчитывать на полную безопасность своего существования, если не будет налицо организации, выходящей за рамки отдельного государства, федерации всех государств, которые взаимно гарантировали бы друг другу неприкосновенность своего устройства» (Шеллинг Ф.В.И. Система трансцендентального идеализма. ОГИЗ. СОЦЭКГИЗ. 1936. С. 354). В геополитическом замысле молодого Шеллинга содержалась идея о том, что «на случай распри между народами будет создан один общий ареопаг из народов, куда будут входить представители всех культурных наций; ему-то и будет предоставлено право использовании совместного могущества всех стран против того или иного отдельного государственного образования, которое может оказаться мятежным» (Там же. С. 354-355). Проект Шеллинга остался практически нереализованным, поскольку путь к единому миру только лишь в границах одной Европы неоднократно прерывался политическими конфликтами, кровопролитными революциями, локальными и общеевропейскими войнами. После Лиги наций, созданной в 1919 году, по окончании Второй мировой войны была образована Организация Объединённых Наций, на протяжении всего послевоенного периода исполнявшая миссию «ареопага из народов», предусмотренную проектом Шеллинга. Деятельность ООН, отмечающей в этом году 75-летний юбилей, является одним из конкретных примеров заботы мирового сообщества об исключительно земном благополучии человечества. В то же время в документах $\mathrm{OOH}$, как и в конституциях большинства европейских государств, включая Россию, не содержится универсальных в мировоззренческом плане положений, относящихся к вопросам высокого достоинства человека как носителя образа Божия, бессмертия его души, его ответственного отношения к смыслу жизни в перспективе вечности. Лишение человека привилегии богоподобного достоинства, потеря смысла его высокого предназначения в предвечном божественном предопределении, отсутствие нравственной ответственности за моральное убожество и духовную непреображённость души, забвение о будущем небесном воздаянии, воскресении и вечной жизни стали характерными чертами цивилизации новейшего времени.

Вплоть до XIX века включительно в связи с мировоззренческой традицией античности, христианства и религиозной европейской философии человек объявлял- 
ся «гражданином двух миров» (Кассирер Э. Избранное. Логика наук о культуре. М.-СПб., 2016. С. 24). Покидая мир земной, человек становился гражданином мира небесного. Ни блуждание призрака смерти на горизонтах человеческой судьбы, ни ущербность и хрупкость земного существования не имели для прошлых эпох перед лицом вечности принципиального и тем более какого-то абсолютного значения. «С тоской и томлением, - отмечает Ричард Нибур, - озираемся мы на прошлые эпохи, когда, как нам кажется, уверенность в Едином Боге была всепронизывающей человеческой верой: например, на раннее христианство или церковное общество средних веков, или на раннее протестантство, или пуританскую Новую Англию, или благочестивый XIX век» (Нибур Р. Радикальный монотеизм и западная культура.//Христос и культура. М., 1996. С. 248). Как и Р. Нибур, А.Ф. Лосев, определяя сущность религии, употребил такой концепт, как «принцип мистической всепроникновенности» (Лосев А.Ф. Высший синтез. М., 2005. С. 122) и утверждал, что именно «Православие - онтологическая основа нашей национальности» (Там же. С. 114).

События этого года, вызванные распространением в планетарном масштабе эпидемии нового опасного вируса, парализовавшего традиционный ритм жизни миллионов людей, вызвали во всём мире волну алармистских настроений и создали возможные предпосылки для мировоззренческой ревизии доминирующей в наше время нигилистической установки. Возникает вопрос: «Не ведёт ли дорога, по которой мы стали двигаться, в тупик?» (Кассирер Э. Избранное. Логика наук о культуре. М.- СПб., 2016. С. 30). Не проигрывает ли в аксиоматическом плане материально-технический прогресс традиционному историческому пути европейской цивилизации, инспирированной христианским учением о вечной жизни и Царстве Небесном? Во всяком случае, следует признать как вполне очевидную аксиому, что «перед требованием - следовать за Богом в Царство Божие, ничтожны все другие задачи» (Ясперс К. Великие философы. Книга первая. М., 2018. С. 244).

В свете происходящих в мире событий не остаётся сомнений в том, что 2020 год станет определённой вехой, обозначающей новый поворот в культурной и интеллектуальной истории человечества. Будет ли этот год началом построения после относительно долгого мрака религиозного и нравственного одичания новой культурной и мировоззренческой парадигмы, означающей «пробуждение к грядущему дню, накануне которого мы стоим» (Деррида Ж. Поля философии. М., 2012. С. 168)? Станет ли более одухотворённым современный мир, решительно расстающийся с прошлой эпохой, от которой остаётся лишь «ностальгически воскрешаемая реальность во всех её формах» (Бодрийяр Ж. Символический обмен и смерть. М., 2015. С. 45)? Произойдёт ли подлинное возрождение идеалов добра, честности, справедли-

\section{вости, умеренности, скромности, благородства?}

«Там, где разум даёт пространство, исчезают иллюзии, проходят упоение и дикость» (Ясперс К. Разум и экзистенция. М., 2014. С. 311). Вероятно, вполне возможна, согласно К.Ясперсу, новая парадигмальная ситуация, несущая печать искренней приверженности новых генераций и новых обществ символам и традициям веры, когда «принципиально всё может стать святым» (Там же. С. 249). Сам Ясперс не исключает надежды, что философия в своём восприятии экзистенциальной действительности сумеет обрести трансценденцию из истоков своей свободы «именно, как специфически святое - в мире» (Там же. С. 249). Новое обретение трансцендеции, являющейся смысловым ключом к объяснению преходящей эмпирической действительности, воспринимается как миссия, которую К. Ясперс возлагает на философию в условиях современной ситуации. Призванием философии становится задача преодоления мировоззренческой растерянности на пороге новой глобальной реальности, когда радикально меняется на наших глазах не только традиционная картина мира, меняются горизонты запрограммированной реальности, меняются в социальном пространстве географические параметры Земли (Гилинский Я. Девиантность в обществе постмодерна. СПб., 2017. С. 27), ощущается «абсолютный дефицит времени, то есть смерть» (Бодрийяр Ж. Символический обмен и смерть. М., 2015. С. 264). Наступает некий виртуальный Апокалипсис, который имеет место здесь и теперь. Над человечеством нависла угроза глобального эсхатологического финализма, угроза сени смертной, как результат всеобщего глобального кризиса, который Ж.Бодрийяр назвал «кризисом реализованной утопии» (Грицанов О.А. «Америка» //Постмодернизм. Новейший философский словарь. Минск, 2007. С. 6) с её неограниченной либерализацией, трансформировавшейся в гиперреальность, где «безраздельно царствует новая непристойность» (Галкин Д.В. Грицанов А.А. Бодрийяр // Постмодернизм. Новейший философский словарь. Минск, 2007. С. 61).

Если греческое миросозерцание было окружено «возвышенной непостижимостью мойр» (Ясперс К. Разум и экзистенция. М., 2014. С. 5), под покровительством которых находились рождение и смерть человека, то это означает лишь принципиальную безошибочность религиозной интуиции древних эллинов в их восприимчивости к небесному миру. Как констатирует Г. Марсель, человек современной западной культуры решительно утратил «контакт с той фундаментальной истиной» (Marcel G. Etre et avoir. Paris, 1935. P. 281), которая в прежние эпохи открывала ему присутствие Бога в его индивидуальном образе жизни. «Смерть - это последний и окончательный удел человека. Поэтому о мойре смерти говорят чаще, чем о любой другой» (Geschichte der griechischen Religion. Vol. 1. Munich, 1955. P. 339). 
В своей книге «Символический обмен и смерть» Ж. Бодрийяр писал: «Вся наша культура - это сплошное усилие отъединить жизнь от смерти... жизнь как накопление, смерть как расплата» (Бодрийяр Ж. Символический обмен и смерть. М., 2015. С. 264). По Бодрийяру, «Страшный суд уже происходит, уже совершается у нас на глазах - это зрелище нашей собственной кристаллизованной смерти» (Галкин Д.В. Грицанов А.А. Бодрийяр. // Постмодернизм. Новейший философский словарь. Минск, 2007. С. 62). События драматической реальности воспринимаются как сигнал, который нас «убеждает в существовании высших смыслов, очищенных от фактов обыденного бытия людей» (Уайтхед А.Н. Избранные работы по философии. М., 1990. С. 415). Жизнь и смерть как важнейшие экзистенциалы сущего открываются человеку всякий раз в парадигме новой экзистенциальной ситуации в качестве феноменальных событий его бытия. Онтологической привилегией человека является, согласно М. Хайдеггеру, его способность «отозваться на бытие» (Хайдеггер М. Время и бытие. М., 1993. С. 255), то есть отозваться на зов бытия, и «через эту отзывчивость принадлежать бытию» (Там же. С. 255). Тем не менее, величие человека Хайдеггер облекает в коннотации исключительно пессимистического характера, навеянные угрозой тревоги, которую П. Тиллих определяет как «экзистенциальное осознание небытия» (Тиллих П. Избранное. Теология культуры. М., 1995. С. 30). Хайдеггер говорит о тоске как неизбежном спутнике экзистенции: «Глубокая тоска, бродящая в безднах нашего бытия, словно глухой туман, смещает все вещи, людей и тебя самого вместе с ними в одну массу какого-то странного безразличия. Этой тоской приоткрывается сущее в целом» (Хайдеггер М. Время и бытие. М., 1993. С. 20). Хайдеггер ничего не говорит о метафизических основаниях сущего, для него развитие метафизики связано с всемирно-исторической судьбой европейской цивилизации, теряющей, как он полагал, свой подлинный смысл по мере прогрессирующего «забывания бытия». В оценке А. Хаутепена, выросшего на новом богословском прочтении Хайдеггера, смысл диалога интерпретаций состоит в том, «что Бог не умаляет человеческого достоинства и что истинная религия не знает противоречий с идеалами истинного гуманизма» (Хаутепен А. Бог: открытый вопрос. М., 2008. С. 366). Хаутепен убеждён, что «в критическом диалоге о религиозных представлениях» (Там же. С. 371), несмотря на постмодернистское свидетельство о смерти гуманизма и субъекта, историческая онтология существования в философии Хайдеггера всё же оставляет возможность философского вопроса о Боге и что «в конечном итоге воссияет правда о Боге» (Там же. С. 371). В этом плане Хайдеггер может рассматриваться «как фигура религиозного пантеона, как «посланник самого бытия», провозвестник и подготовитель величайшего события, в котором завершится старая история европейского мира и начнётся новая, никогда доселе не бывшая» (Дугин А.Г. Мартин Хайдеггер. Философия дру- гого начала. М., 2010. С. 11-12). На фоне совершающихся в современном мире событий Хайдеггер воспринимается не только как навеки вошедший в историю мировой философии завершитель философии эпохи модерна. «Хайдеггер открывается как фигура эсхатологическая, как финальный толкователь и изъяснитель самых глубоких и загадочных тем мировой философии и создатель радикально нового мышления» (Там же. С. 11).

В отличие от Хайдеггера, в интуиции Ж. Бодрийяра акцент смещается в сторону потери современным человеком трансцендентного смысла существования. «Моим предметом, - признавался Бодрийяр, - является скорее общество, теряющее трансцендентность» (Галкин Д.В. Грицанов А.А. Бодрийяр. // Постмодернизм. Новейший философский словарь. Минск, 2007. С. 63). Но, как заметил А. Тойнби, «сколь бы ни расширялась пропасть между традиционной религиозной ортодоксией и текущим непосредственным опытом, она, в конце концов, преодолевается некоторой формой религиозного возрождения» (Тойнби А.Дж. Постижение истории. М., 1996. С. 503). Ситуация может измениться в любой момент человеческой истории в направлении вектора, соотносимого с абсолютным и изначальным замыслом, положенным в основание архетипического построения бытия. Так, в наш современный мир, глубоко и беспредельно погружённый в стихию исключительно имманентных интересов, вдруг совершенно неожиданно и противоестественно вошёл фактор, отмеченный маркером своей исключительной трансцендентной значимости, поставивший под сомнение глубинный фундаментальный вопрос об абсолютном смысле человеческой экзистенции. В своей радикальной философской постановке вопрос может быть сформулирован в формате рациональной апории: если в смерти нет никакого смысла, то есть ли смысл в самой жизни, неизбежно завершающейся неотвратимостью смерти? Положительное решение вопроса необходимо предполагает признание за человеческой личностью индивидуального бессмертия в вечности. Ключевая роль религии в земном существовании человека состоит в том, что она «придаёт значение всему преходящему» (Уайтхед А.Н. Избранные работы по философии. М., 1990. С. 253). В Божественном Откровении человеку даётся видение того, что находится за пределами имманентного опыта. Это видение не требует ничего, кроме поклонения и любви (Там же. С.254). Но «поклонение Богу не есть забота о безопасности, оно есть смелое предприятие духа, полёт к недостижимому» (Там же. С. 254). В новое время, утратив религиозный энтузиазм, «массы не приняли, полагает Бодрийяр, саму Идею Божественного» (Грицанов А.А. «В тени молчаливых большиств, или конец социального» // Постмодернизм. Новейший философский словарь. Минск, 2007. С. 69) и связанные с ней концепты трансцендентной реальности: веру, молитву, благочестие, аскезу, терпение, нравственность, благородство. Подавляющее большинство 
живущих в мире людей ориентировано на потребительство и комфорт, чтобы на подсознательном уровне исключить мысль о неизбежности смерти в надежде на то, что жизнь, в конце концов, потеряет для них свою прежнюю ценность и привлекательность, чего в действительности как правило не происходит, и человеку в состоянии аффекта ужаса перед разверзающейся зияющей бездной смерти свойственно до самого последнего вздоха судорожно цепляться за жизнь. «Ужасом приоткрывается Ничто» (Хайдеггер М. Время и бытие. М., 1993. С. 21), говорит о последнем мгновении бытия Хайдеггер. В ужасе «само Ничто выходит из своей потаённости» (Там же. С.23), «в ужасе происходит отшатывание» (Там же. С. 22) от Ничто, когда «земля уходит из-под ног» (Там ж. С. 21), и человеку «не на что опереться» (Там же. С, 21), потому что ускользает, уходит «сущее в целом» (Там же. С. 21). Человек, как заметил П. Тиллих, обычно «не сознаёт, что небытие и тревога присутствуют в глубине его личности» (Тиллих П. Избранное. Теология культуры. М., 1995. С. 52). Даже мужество «не устраняет тревогу: тревога экзистенциальна, и её невозможно устранить» (Там же. С. 49-50). Экзистенциальная тревога не устраняется и верой в прогресс, берущей своё начало от Аристотеля. Однако «у Аристотеля движение от потенциальности к актуальности вертикально, т.е. идёт от низших к высшим формам бытия» (Там же. С. 76), тогда как «прогрессивизм Нового времени рассматривает это движение как горизонтальное, протекающее во времени и направленное в будущее» (Там же. С. 76). Идея земного прогресса принуждает человека жить верой в счастье будущих поколений. Но «как говорил Ортега-и-Гассет, не можем же мы отложить жизнь на потом, пока учёные не объявят, что для жизни всё готово» (Уотсон П. Эпоха пустоты. М., 2017.С. 707). Веру в прогресс П. Тиллих расценивает в качестве главной формы человеческого самоутверждения перед лицом экзистенциальной тревоги в парадигме «западной цивилизации Нового времени» (Тиллих П. Избранное. Теология культуры. М., 1995. С. 76), в условиях которой люди, стремящиеся скрыться по причине своих личных грехов от Бога, охвачены угрозой тревоги. Тревога «выходит из-под контроля и становится разрушительной» (Там же. С. 66).

Уникальность современной ситуации определяется тем обстоятельством, что ещё никогда во всей своей прошлой истории человечество не переживало такой тревоги, которая в короткое время смогла охватить население земного шара и вызвать со стороны правительств государств Европы, Азии и Америки ответные меры, которые остановили привычный ритм жизни в таких сферах человеческой деятельности как экономика, образование, культура, международное общение. Начиная с весны этого года, человечество осознало таящуюся принципиальную нестабильность и хрупкость своего существования в мире, казалось бы, радикально преобразованном творческой человеческой деятельностью, но ставшего вдруг в своей природной стихии источником смертельной угрозы для каждого жителя земли. Осознание нависшей опасности коренным образом трансформировало привычную традиционную картину мира. Жизнь как бы замерла и притаилась перед лицом реальной угрозы небытия, вызванной распространением эпидемии нового вируса, последствия которой стали главной темой в источниках информации для миллионов людей. «Ни полиция, ни армия, никакие институты власти с её потенциалом насилия ничего не могут сделать против ничтожно малой, но зато символической гибели одного или нескольких людей» Бодрийяр Ж. Символический обмен и смерть. М., 2015. С. 100). Принимая вызов, система может умереть и развалиться, поскольку «вызов обладает смертоносной эффективностью» (Там же. С. 100). Эту непреложную аксиому наше общество открывает для себя вновь. «Пути альтернативной политики - это пути символической эффективности» (Там же. С. 100).

Тревога, охватившая мир, становится разрушительной. Она носит глобальный характер в силу глобального образа жизни как общего для всех людей способа повседневного существования. В современном глобальном мире каждый индивидуум превратился в сознательного бонвивана, смыслом жизни которого является неограниченное и беспрестанное потребление товаров и услуг. Его судьба, безопасность и благополучие покоятся на обладании личной собственностью. Большинство людей в современном мире «обладают одной и той же мотивацией, и, больше того, они восприимчивы к одним и тем же идеям и идеалам» (Фромм Э. Душа человека. М., 1992. С. 330). Глобальное потребление формирует глобальный тропос существования, modus vitae. «Формирующийся глобальный образ жизни вдохновляется едиными для всей планеты моделями поведения, культурой и идеологией, героями и эталонами» (Добреньков В.И. Рахманов А.Б. Социология глобализации. М., 2014. С. 251).

В отличие от Европы с её кризисом исторических идеалов, Америка с её кризисом реализованной утопии свободы и изобилия является в оценке Ж. Бодрийяра «страной без надежды», где «мысль о физическом или нервном истощении не даёт покоя, и смысл смерти для всех заключается в её постоянном предупреждении» (Грицанов О.А. «Америка» // Постмодернизм. Новейший философский словарь. Минск, 2007. С. 7). В современном мире глобальный образ жизни заслоняет и вытесняет национальную и культурную самобытность, присущую различным цивилизациям и этносам. В наше время "В разных странах, на континентах планеты люди потребляют одну и ту же пищу, носят одну и ту же одежду, слушают одну и ту же музыку, смотрят одни и те же фильмы и телепередачи, получают информацию из рук одних и тех же средств массовой информации, восторгаются одними и теми же кинозвёздами и спортсменами» (Добреньков В.И. Рахманов А.Б. Социология глобализации. М., 2014. 
C. 251). Экзистенциальная потребность, проявляющаяся в стремлении людей быть как все, обусловлена, несомненно, факторами социокультурного характера, однако на глубинном подсознательном уровне эта потребность продиктована метафизической тревогой, вызванной страхом смерти, и эта тревога инстинктивно влечёт индивидуум к поиску гарантий безопасности и спасения там, где большинство, где все. В своих общих чертах глобализация открывается как культура потребления, стандарты которой преподносятся в информационных сетях и в рекламе современного стиля жизни. При этом национальное своеобразие региональных культур, их оригинальность, уникальность и ценность могут преподноситься как пережитки прошлого, как отсталость и дикость. Благодаря процессам экономической интеграции, происходит неуклонное возрастание влияния западноевропейской массовой культуры на традиционные мировые культуры. «Влияние Западной Европы и США на них не всегда носит характер диалога. В ряде случаев данное влияние приводит к вырождению самобытности культур и даже к духовной и моральной деградации их носителей» (Докучаев И.И. Ценность и экзистенция. СПб., 2009. С. 563-564). В результате аналитического подхода к изучению феномена глобализации можно было бы вполне объективно признать наличие двух видов человеческих фобий, лежащих в его психологическом основании: экзистенциальный страх отчуждённости, покинутости и оставленности и метафизическая тревога, вызванная неотвязчивой угрозой страха смерти. Как показывает история нравственной философии от Аристотеля до П. Тиллиха, оба вида фобий требуют для их преодоления со стороны человека проявления добродетелей веры и мужества.

Согласно Аристотелю, мотивом мужественного противостояния реальной неизбежности смерти является благородство. Мужественный человек действует «ради благородной цели, ибо цель добродетели - благородное» (Аристотель. Никомахова этика. III. 7). В своей принадлежности к идеальному порядку бытия благородство «неизбежно присуще немногим» (Гартман Н. Этика. СПб., 2002. С. 382). Благородными личностями являются «легендарные герои человечества, те, кто вызывает восхищение, любовь и поклонение, истинные чада Божии, чьи имена не прейдут в эонах» (Юнг К.Г. Бог и бессознательное. М., 1998. С. 463). Благородство означает верность Божественному предназначению. Кто благороден, «кто имеет предназначение, кто слышит голос глубин, тот обречён» (Там же. С. 464). В отношении благородного человека Аристотель употребляет тот же термин «kalos», который Иоанн Богослов употребляет в Евангелии, где Христос называет Себя «pimen kalos» - «превосходным», «доблестным», пастырем, доблесть которого заключается в свободном и победоносном шествии навстречу смерти, в полагании своей жизни за жизнь мира, поскольку «на смерть можно ответить только другой, равной или большей смертью» (Бодрийяр Ж. Символический обмен и смерть. М., 2015. С. 98).

Во Христе открывается эра мирового христианства. Пепельная грусть умирающего эллинизма сменяется радостью апостольского благовестия Царства Божьего (Троицкий В. Очерки по истории догмата о Церкви. Сергиев Посад, 1912). Керигма возвещается в Римской империи среди господства «холодного своекорыстного насилия»

(Гегель Г.В.Ф. Философия права. М.,1990. С. 376), в атмосфере, отравленной «испорченностью черни» (Там же. С. 376). Новому христианскому этносу дан ключ к решению всех экзистенциальных проблем: «Ищите же прежде Царства Божьего и правды его, и это всё приложится вам» (Мф. 6, 33). «Антипод римской мании величия, которая была свойственна не только Цезарю, но каждому римлянину - «сіvis Romanus sum», возник в христианстве, которое, заметим между прочим, было единственной религией, действительно подвергавшейся преследованиям со стороны римлян. Противоречие обнаруживало себя везде, где бы не сталкивались друг с другом культ цезарей и христианство» (Юнг К.Г. Бог и бессознательное. М., 1998.С. 469). Христос - Мессия, свою мессианскую роль Он исполнил через свою смерть (Ричард Хейз. Этика Нового Завета. М., 2005. С. 227). В ней Христос открыл своё Божественное достоинство, «приняв на себя не земную славу, а позор и земное страдание» (Розеншток-Хюсси О. Язык рода человеческого. М.,- СПб., 2000. С. 485). В своём Воплощении и в своей свободной и искупительной смерти Он стал солидарен со всеми живущими и умершими, стал таким, каким является каждый из нас, чтобы Божественная жизнь, сосредоточенная в Нём как в одном человеке, могла затем от Него передаться всем (Там же. С. 484). Своей победой над смертью, победой, которая в своём универсализме действительно была триумфальной, Христос открыл человечеству врата Небесного Царства. «Там, где весь еврейский народ ожидал в качестве Мессии столь же имперского, сколь и политически всесильного героя, Христос выполнил мессианское предназначение не столько для своей нации, сколько для романского мира, и указал человечеству на древнюю истину: там, где господствует любовь, сила не имеет значения» (Юнг К.Г. Бог и бессознательное. М., 1998. С. 470). Он стал победителем смерти во всех событиях своей жизни, в Гефсимании и на Голгофе, и «именно таким победителем пришёл Он снова, открылся своим ученикам в пасхальном событии» (Барт К. Церковная догматика. Том 3. М., 2014. С. 236).

Богословие Церкви «превращает «смерть» и «жизнь» в символы качества и способа существования в настоящем» (Ричард Хейз. Этика Нового Завета. М., 2005. С. 195). В богословской концепции апостола Павла событие смерти и Воскресения Христа, будучи ноу- 
менальным основанием Нового Завета, связывается с онтологическим призванием человека, каким является исполнение им Божественного предназначения под знаком надежды воскресения и будущей вечной жизни. Парадигма земного существования человека имеет своим метафизическим основанием предвечный замысел Бога. «Завет между Богом и человеком есть первый и последний смысл истории» (Барт К. Церковная догматика. Том 3. М., 2014. С. 313), которая, несмотря на свой преходящий характер, обязана своим потаённым смыслом находящейся за пределами времени вечности. Но уже здесь и теперь вечность сообщает глубинные смысловые коэффициенты, придающие безусловное оправдание необъятности и величию вселенского природного бытия, ознаменованного преобразовательной деятельностью человека в культурно-историческом цивилизационном процессе.

Акмеической фазой в культурной истории человечества является христианская культура Европы, которую Т.С. Элиот называет величайшей из всех, когда-либо существовавших. Религия, пока она жива, отмечал Элиот, образует «рамку» культуры, оберегает человеческие массы от скуки и отчаяния, придаёт смысл жизни (Eliot T. S. Notes Towards the Definition of Culture. London. Faber and Faber, 1948. Р. 19), ибо, как сказал Макс Вебер, без религии жизнь утратила бы «своё очарование» (Уотсон П. Эпоха пустоты. М., 2017. С. 708). В современном мире, где господствует тревога судьбы и смерти, тревога вины и осуждения, тревога отсутствия смысла, «жало страха тревога, а тревога стремится стать страхом» (Тиллих П. Избранное. Теология культуры. М., 1995. С. 31). В ситуации экзистенциального осознания небытия «страх смерти вносит элемент тревоги в любой другой вид страха» (Там же. С. 30). Тревога поворачивается лицом к тому, чьей собственностью является подаренный Богом бесценный дар бытия в его открытости для жизни и смерти. В событиях Воплощения и Воскресения Бог стал самым глубоким метафизическим основанием человеческого существования. Через событие крещения человек преодолевает свою заброшенность и отчуждённость, ноуменально облекается во Христа, и в этом событии его бытие становится собственным бытием. «Что за этим последует? На это Хайдеггер отвечает: «Появится Последний Бог» (Дугин А.Г. Мартин Хайдеггер. Метаполитика. Эсхатология бытия. М., 2016. С.121). Целью своей философии Хайдеггер ставил создание фундаментальной онтологии, в которой задуманная им модель политического устройства и космического таксиса заключает в себе проект, рождающийся из глубин самого бытия. «Последний Бог явится на горизонте аутентичного экзистирования. Человек может создать политическую систему, человек способен организовать космос, но человек сам никогда не сможет заменить собой и своими конструктами Теополис, Божественный Град. «Ноэтическая политейя не дело рук человека», даёт понять Хайдеггер»
Там же. С. 121). Уделом человека, как говорит П. Рикёр, является его открытость «ко всем ценностям всех людей и всех культур» (Рикёр П. Философская антропология. М., 2017. С. 23). В своём антропологическом измерении эсхатологический проект Хайдеггера напоминает «Философию общего дела» Н. Ф. Фёдорова, испытавшего влияние идей В.С. Соловьёва в его воззрениях на историю как на богочеловеческий процесс. В своём стремлении преодолеть секулярный дух философии Нового времени Соловьёв считал своей целью «ввести вечное содержание христианства» (Соловьёв В.С. Письма. СПб., 1911. Т. 2. С. 89) в порядок современной ему действительности. В оценке В.С. Соловьёва учение Н.Ф. Фёдорова является «первым движением человеческого духа вперёд по пути Христову» (Семёнова С.Г. Фёдоров. // Русская философия. Энциклопедия. М., 2020. С.747). В философии Н.Ф. Фёдорова Бог действует в мире через человека и через него Он исполнит эсхатологические обетования. Финал истории, как и у Хайдеггера, у Фёдорова зависит от самих людей, от их обращения «на Божьи пути» (Там же. С. 748). В перспективе эсхатологического ожидания Бога Хайдеггер ставит акцент на том, что «Он ждёт нас» (Дугин А.Г. Мартин Хайдеггер. Метаполитика. Эсхатология бытия. М., 2016. С.121). Под хайдеггеровский проект экзистенциальной политики А.Г. Дугин подводит евангельское обоснование: «Царствие Божие внутрь вас есть», оно не есть вне вас, оно внутри» (Там же. С. 122). Интерпретируя Хайдеггера, А.Г.Дугин поясняет: «Он ждёт, когда мы проснёмся и построим ту политическую систему, осуществим тот космический план, тот проект, тот набросок, которые будут совместимы с возможностью его прихода» (Там же. С. 121). В интерпретации эсхатологической проблемы как самим Хайдеггером, так и А.Г. Дугиным, открываются концептуальные параллели, которые мы находим не только у В.С. Соловьёва и Н.Ф. Фёдорова, но, например, также и у современного афонского архимандрита Эмилиана (Вафидиса): «Нас ждёт Отец, Бог, Который хочет укрыться в нашем сердце» (Эмилиан, архимандрит. Толкование на подвижнические слова аввы Исаии». Екатеринбург, 2017. С.547). И только лишь по причине нашей человеческой инертности, косности, праздности, неверности, «не желая исполнять Его волю, мы навечно Его теряем - таков наш удел» (Там же. С. 549). «Как ветвь не может приносить плода сама собою, если не будет на лозе, так и вы, если не будете во Мне» (Ин. 15,4). Исходя из своего личного опыта афонский подвижник говорит примерно то же самое, что и Арнольд Тойнби: «Грешник будет уничтожен не вмешательством Бога, а своим собственным деянием. И грех его не в том, что он вступил в соперничество с Творцом, а в том, что он тщательно изолировал себя от него. Роль Бога в этой человеческой трагедии не активна, а пассивна. Погибель грешника не в божественной ревности, а в неспособности Бога продолжить использовать в качестве творения существо, упорствующее в самоотчуждении от Творца своего (Еф. 4,18). Грешная душа движется к горькой рас- 
плате, ибо, пребывая в грехе, она закрыта для божественной благодати» (Тойнби А.Дж. Постижение истории. М., 1996. С.253). В следовании за Богом, в актуальном исполнении Евангелия, человек осуществляет синтез свободы и жертвы, который «вечно нов, ибо он - в духе вечной правды христианства» (Левицкий С.А. Свобода и ответственность. М., 2003. С. 375).

На протяжении всего Нового времени тенденция оптимизации жизни выполняла роль доминантной установки в природно-космическом самоопределении человека. Она была инспирирована идеей прогресса, создающего необходимые внешние предпосылки для обеспечения свободы, комфорта и потребительства. Когда преодолена нужда, когда достигнут комфорт, когда душа погружается в состояние шопенгауэрской скуки, возникает бодрияровский вопрос, что делать дальше и чего ждать под надвигающейся тревожной и мрачной сенью, в которой витает призрак неотвратимой смерти. Наступает глубинный онтологический кризис, состояние полной психологической резиньяции, с её бесчувственной атрофией по отношению ко всему спектру экзистенциальных проблем. Перед лицом открывающейся меональной реальности ставится под сомнение весь грандиозный гуманистический проект, исключающий малейший луч надежды на вечную жизнь. Единственной альтернативой бытийной безысходности в глобальном цивилизационном масштабе может стать лишь новое одухотворённое отношение к миру как необходимой предпосылки грядущего Царства Божьего, наступление которого предполагает реализацию глубинного религиозного, интеллектуального и нравственного ресурса каждой отдельной человеческой личностью и всего человечества в целом.

\section{ЛИТЕРАТУРА}

1. Аристотель. Никомахова этика (Перевод Э.Л.Радлова) // Радлов Э.Л. Этика Аристотеля. СПб., 1908.

2. Барт К. Церковная догматика. Том 3. М., 2014.

3. Бодрийяр Ж. Символический обмен и смерть. М., 2015.

4. Галкин Д.В. Грицанов А.А. Бодрийяр. //Постмодернизм. Новейший философский словарь. Минск, 2007.

5. Гартман Н. Этика. СПб., 2002.

6. Гегель Г.В.Ф. Философия права. М., 1990.

7. Грицанов А.А. «В тени молчаливых большинств, или конец социального» //Постмодернизм. Новейший философский словарь. Минск, 2007.

8. Грицанов О.А. «Америка». // Постмодернизм. Новейший энциклопедический словарь. Минск, 2007.

9. Гилинский Я. Девиантность в обществе постмодерна. СПб., 2017.

10. Деррида Ж. Поля философии. М., 2012.

11. Добреньков В.И. Рахманов А.Б. Социология глобализма. М., 2014.

12. Докучаев И.И. Ценность и экзистенция. СПб., 2009.

13. Дугин А.Г. Мартин Хайдеггер. Метаполитика. Эсхатология бытия. М., 2016.

14. Дугин А.Г. Мартин Хайдеггер. Философия другого начала. М., 2010.

15. Кассирер Э. Избранное. Логика наук о культуре. М., 2016.

16. Левицкий С.А. Свобода и ответственность. М., 2003.

17. Лосев А.Ф. Высший синтез. М., 2005.

18. Нибур Р. Радикальный монотеизм и западная культура. // Христос и культура. М., 1996.

19. Рикёр П. Философская антропология. М., 2017.

20. Семёнова С.Г. Фёдоров. //Русская философия. Энциклопедия. М., 2020.

21. Соловьёв В.С. Письма. Т. 2. СПб., 1911.

22. Тиллих П. Избранное. Теология культуры. М., 1995.

23. Тойнби А.Дж. Постижение истории. М., 1996.

24. Троицкий В. Очерки по истории догмата о Церкви. Сергиев Посад, 1912.

25. Уайтхед А.Н. Избранные работы по философии. М., 1990.

26. Уотсон П. Эпоха пустоты. М., 2017.

27. Фромм Э. Душа человека. М., 1992.

28. Хайдеггер М. Время и бытие. М., 1993.

29. Хаутепен А. Бог: открытый вопрос. М., 2008.

30. Хейз Р. Этика Нового Завета. М., 2005.

31. Шеллинг Г.В.И. Система трансцендентального идеализма. ОГИЗ. СОЦЭКГИЗ. 1936.

32. Эмилиан (Вафидис), архимандрит. Толкование на подвижнические слова аввы Исаии. Екатеринбург, 2017.

33. Юнг К.Г. Бог и бессознательное. М., 1998.

34. Ясперс К. Разум и экзистенция. М., 2014. 
35. Ясперс К. Великие философы. Книга первая. М., 2018.

36. Eliot T. S. Notes Towards the Definition of Culture. London. Faber and Faber, 1948.

37. Marcel G. Etre et avoir. Paris, 1935.

38. Geschichte der griechischen Religion. Vol. I. Munich, 1955.

○ Саврей Валерий Яковлевич (vsvry@icloud.com).

Журнал «Современная наука: актуальные проблемы теории и практики»

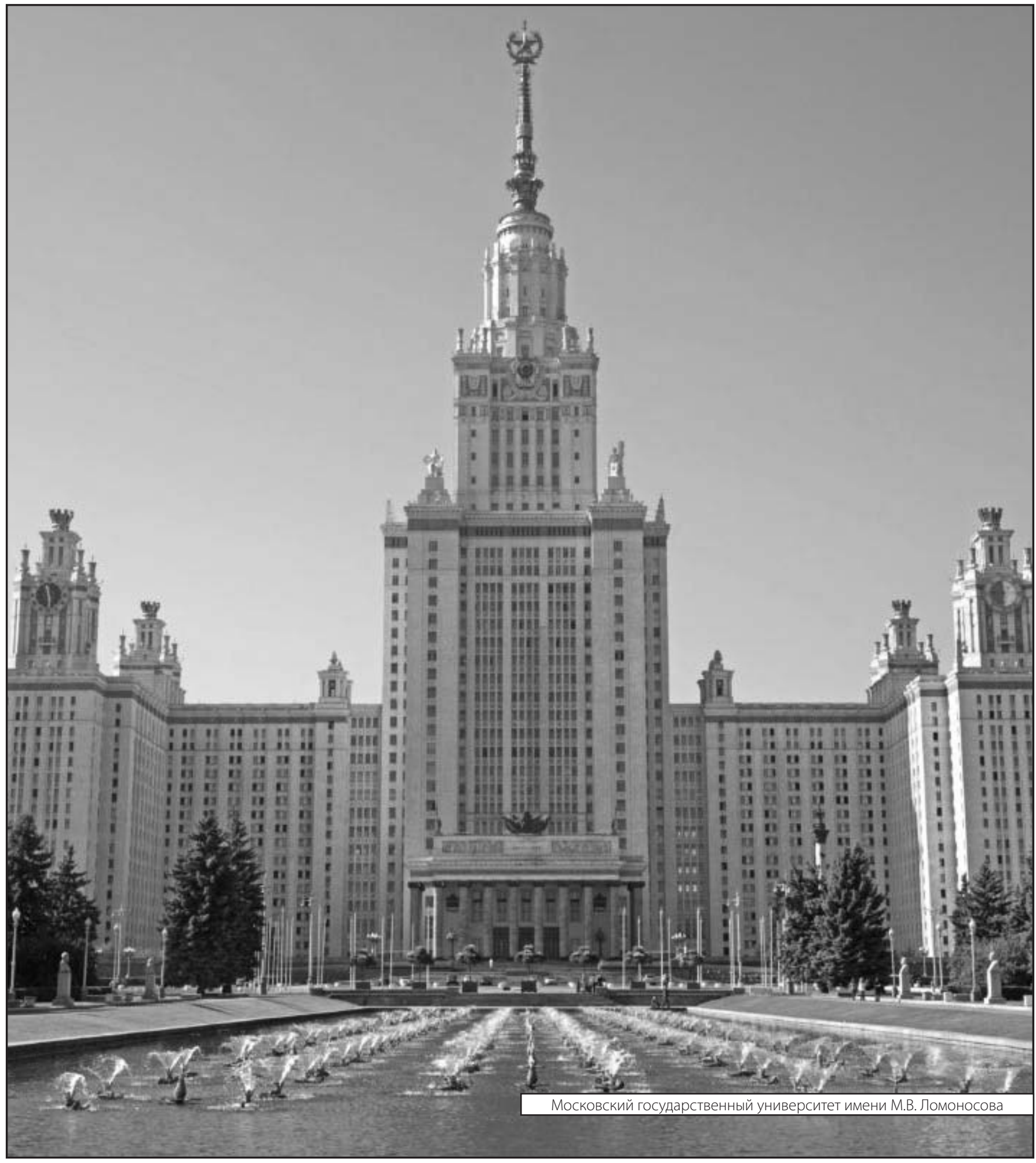

